\title{
Identity Development during Undergraduate Research in Mathematics Education
}

\author{
Randall E. Groth \& Jenny McFadden \\ Salisbury University, Department of Education Specialties, USA
}

•Received 11 November $2015 \bullet$ Revised 05 February $2016 \bullet$ Accepted 05 February 2016

We describe a model that leverages natural connections between undergraduate research and mathematics teacher preparation. The model integrates teaching and research by prompting undergraduates to continuously reflect on classroom data from lessons they have taught. It is designed to help undergraduates build identities as teachers who base decisions on empirical data, and also to build identities as future graduate students in mathematics education. The identities that undergraduates participating in the first year of the project developed pertaining to these roles are described. Undergraduates generally identified with a problem-based approach to teaching and saw themselves as future graduate students in various fields, including mathematics education. Suggestions for improving and adapting the model for use in other settings are also provided.

Keywords: classroom research, formative assessment, identity, reflection, undergraduate research

\section{INTRODUCTION}

Two complementary trends have emerged in postsecondary education: renewed emphasis on preparing teachers who approach classrooms with researchers' mindsets and widespread support for undergraduate research. Evidence of the former trend is found in the increasing use of performance assessments that require teacher candidates to assess the impact of their instruction on students' learning (e.g., American Association of Colleges for Teacher Education \& Stanford Center for Assessment, Learning, and Equity, 2015; Educational Testing Service, 2015). Evidence of the latter trend can be seen in commitments from funding agencies such as the National Science Foundation (NSF) to support undergraduate research and the growing number of publication and presentation venues devoted to disseminating undergraduate research (Council on Undergraduate Research, 2015; $\mathrm{Hu}$ et al., 2008). These two trends have potential to complement one another, since both encourage systematic gathering and analysis of empirical data as a pedagogical technique for helping undergraduates develop knowledge.

Recognizing potential synergies between undergraduate research and teacher preparation, NSF issued a letter requesting proposals for undergraduate research

Correspondence: Randall E. Groth, Ph.D.,

Salisbury University, Department of Education Specialties 1101 Camden Ave. Salisbury, MD 21801 USA

E-mail: regroth@salisbury.edu

doi: $10.29333 /$ iejme/339 
sites focusing on mathematics and science education (Ferrini-Mundy, 2011). This manuscript describes the model for a site related specifically to mathematics teacher education that came about in response to the request. The project was entitled "Preparing Aspiring Teachers to Hypothesize Ways to Assist Young Students" (PATHWAYS). We explain the theoretical basis for the PATHWAYS model and its primary components. We also give voice to the eight undergraduates who participated in the first year of the project, describing their emerging and developing designated identities as teachers, researchers, and teacher/researchers.

\section{THE PATHWAYS MODEL AND ITS THEORETICAL BASIS}

The PATHWAYS model draws upon the participation of four mathematics education faculty mentors, eight undergraduates, and sixteen children from local schools. Four of the undergraduates are in the beginning stages of teacher preparation, having taken a course in education but not yet having taken a teaching methods course. The four advanced undergraduates have completed at least one mathematics teaching methods course. Each beginning undergraduate is paired with an advanced undergraduate. Each pair is then provided a faculty mentor who specializes in mathematics education. This arrangement encourages two layers of mentoring, with the advanced undergraduate helping the beginning undergraduate and the faculty mentor overseeing both. Each triad works on assessing and developing the mathematical thinking of four children over the summer.

The PATHWAYS model is based on the theoretical premise that growth as a teacher and as an undergraduate researcher both depend on a reflective cycle of hypothesis formulation and testing (Dewey, 1933; Schön, 1983). Specifically, it employs Ricks' (2011) process reflection framework. Process reflection is "an active form of reflection that extends and links together separate reflective incidents into cohesive mental continuums as ideas through action" (Ricks, 2011, p. 252). Ricks illustrated the application of process reflection to teacher education with Japanese Lesson Study, which prompts groups of teachers to reflect on lessons to ascertain their effectiveness and then use those reflections to improve future instruction. Process reflection is also implicit in recommendations for conducting research in mathematics education. For example, Ball (2003) recommended a research and development cycle for mathematics education that involves developing theories of teaching and learning, designing curriculum materials based on them, gathering empirical data on their effectiveness, and using the insights that are gathered to refine theory. As theory is refined, the cycle repeats itself. Reflections on the effectiveness of an intervention inform future actions to be taken.

Given that process reflection plays a role in improving both teaching and research, it serves as the theoretical foundation for the PATHWAYS model, which seeks to merge the two worlds. The core reflective cycle for the model is illustrated in Figure 1.

Each portion of the PATHWAYS core reflective cycle aligns with one of the steps of process reflection as described by Ricks (2011). The first step in process reflection is an experiential event to initiate a reflective cycle. This is an unsettling event in need of resolution. The initial experiential event for PATHWAYS undergraduates occurs when they conduct problem-based clinical interviews with children they will be responsible for teaching during the summer. The scripts for the interviews are designed by faculty mentors to help elicit children's thinking within a given content domain and grade level within the Common Core State Standards (CCSSM, National Governors Association for Best Practices \& Council of Chief State School Officers, 2010). Before conducting the interviews, undergraduates read and discuss an article on video-based clinical interviews (Ellemor-Collins \& Wright, 2008), watch video of an experienced mathematics education researcher conducting 
an interview (Learn NC \& Wheatley, 2001), and rehearse by taking turns administering the script to one another. The clinical interviews provide a means for undergraduates to develop firsthand knowledge of how students think about mathematics, an experience that tends to be valued more than obtaining such knowledge through more indirect means (Jenkins, 2010; McDonough, Clarke, \& Clarke, 2002). As children talk aloud about mathematics, unsettling events in need of resolution come in the form of misunderstandings or incomplete understandings the children express.

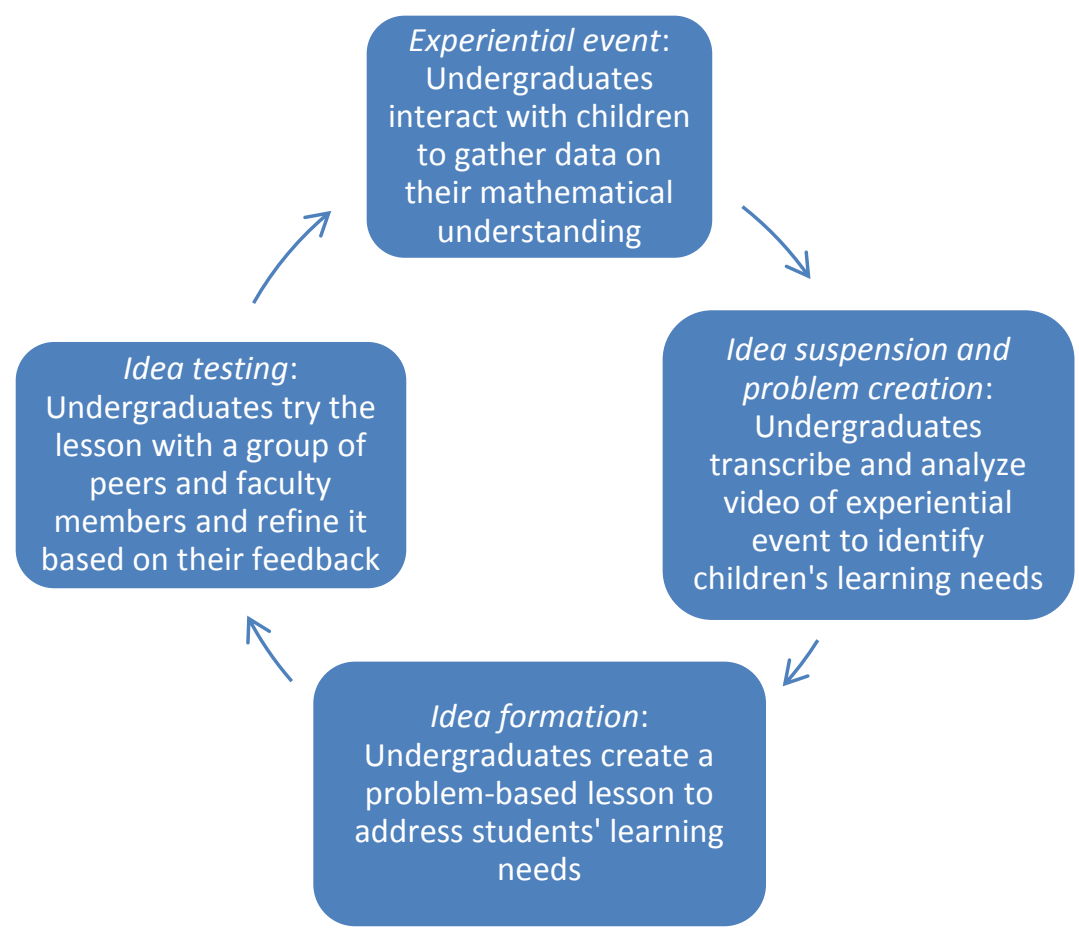

Figure 1. Core reflective cycle for the PATHWAYS undergraduate research model

The second step in process reflection is idea suspension and problem creation (Ricks, 2011). This involves avoiding quick and simplistic solutions in favor of careful analysis. After conducting the initial clinical interviews, PATHWAYS undergraduates work in pairs to engage in structured analysis of the data. First, they transcribe the interviews. Next, they analyze the transcripts by using the five strands of mathematical proficiency model (Kilpatrick, Swafford, \& Findell, 2001). The five strands prompt them to comb through transcripts looking for evidence of children's conceptual understanding, procedural fluency, strategic competence, adaptive reasoning, and productive disposition. Undergraduates read about the five strands before analyzing data, and further refine their understanding of each strand by discussing their interpretations of the data with one another and with their faculty mentor. In the process, they identify specific areas in which children need further mathematical development.

After undergraduates use the five strands as a lens to analyze the data, they engage in the third step of process reflection, idea formation. Idea formation consists of creating possible solutions to problematic events (Ricks, 2011). In the PATHWAYS context, this means creating problem-based lessons to address students' mathematical needs. Undergraduates view and discuss examples of problem-based lessons and become familiar with a three-part "launch-exploresummarize" lesson format (Lappan et al., 2009) before designing lessons. Then, in 
collaboration with a partner and a faculty mentor, they design a problem-based lesson. Undergraduates are introduced to problem-based lessons as those in which students must analyze non-routine problems and design solution strategies by drawing on previous knowledge and collaboration with peers (Learn NC \& Wheatley, 2001). To help in the formation of conjectures about how children's thinking might be fostered, undergraduates are prompted to consult relevant NCTM publications and CCSSM-aligned learning progression documents (e.g., Common Core State Standards Writing Team, 2011; Confrey et al., 2012).

The refined lesson is then used during the fourth step of process reflection, idea testing. Undergraduates do a practice run of the lesson with their larger peer group and faculty mentors. The peer group and faculty mentors react to the lesson in the manner they expect children to react and then make suggestions for improvement. The feedback received at this step helps them further refine the lesson before implementing it with children. Undergraduate pairs then implement the lesson they designed with the group of children they interviewed. They video record the lesson and transcribe it afterward. The lesson with children creates an experiential event to trigger another cycle of process reflection. Participants use the five strands of mathematical proficiency model once again to engage in idea suspension and problem creation by characterizing the mathematical proficiency children exhibited during the lesson. Idea formation again comes in the form of creating a problembased lesson to help children's thinking develop. This leads to another round of idea testing, implementing the lesson, and assessing its effectiveness. Undergraduates travel through the cycle to create seven weekly lessons before their final week with children, which consists of administering the initial clinical interview script once again as a post-assessment.

During the final week of their 10 -week summer experience, undergraduates finalize posters and abstracts to be used for disseminating their findings. To produce these, they work with their faculty mentors to make a final pass through the data to summarize students' learning in terms of the five strands of mathematical proficiency (Kilpatrick et al., 2001). During year 1 of the project, undergraduates presented their final projects at several conferences, including those organized by the Council on Undergraduate Research (CUR), that National Association of Professional Development Schools (NAPDS), and the Mathematical Association of America (MAA). The entire PATHWAYS journey, along with events occurring before and after the core 10-week summer experience, is summarized in Figure 2, and the template for the final poster is shown in Figure 3.

\section{THE PATHWAYS MODEL AND IDENTITY DEVELOPMENT}

The PATHWAYS model is designed to help undergraduates build identities as both mathematics teachers and mathematics education researchers. The need for individuals who self-identify with these professional roles is acute. Many schools have difficulty staffing mathematics teaching positions (Reys \& Reys, 2004). There is not a large reserve supply of mathematics teachers, as there is for some other disciplines (Ingersoll \& Perda, 2010). There is also a need for more qualified students in mathematics education doctoral programs. For example, Reys, Reys, and Estapa (2013) reported that universities in the U.S. have been unable to fill approximately $25 \%$ of their mathematics education positions in recent years. Mathematics education, as a discipline, cannot survive and grow without increasing the numbers of individuals who identify as mathematics teachers and mathematics education researchers. 


\begin{tabular}{|c|c|c|c|c|c|}
\hline \multirow{3}{*}{$\begin{array}{c}\text { One-month } \\
\text { preparatory online } \\
\text { instructional } \\
\text { modules }\end{array}$} & \multicolumn{5}{|c|}{$\begin{array}{l}\text { These introduce: the Common Core State Standards and accompanying learning progressions, the } \\
\text { five strands of mathematical proficiency, the PATHWAYS model, procedures for working with human } \\
\text { subjects, problem-based lessons, and interview scripts to be administered to children }\end{array}$} \\
\hline & Monday & Tuesday & Wednesday & Thursday & Friday \\
\hline & $\begin{array}{l}\text { Orientation to } \\
\text { campus and } \\
\text { review of online } \\
\text { modules }\end{array}$ & $\begin{array}{l}\text { Prepare for } \\
\text { and conduct } \\
\text { initial interviews } \\
\text { with children }\end{array}$ & $\begin{array}{l}\text { View and } \\
\text { transcribe initial } \\
\text { interviews with } \\
\text { children }\end{array}$ & $\begin{array}{l}\text { Analyze } \\
\text { results of } \\
\text { interviews with } \\
\text { children }\end{array}$ & $\begin{array}{l}\text { Begin } \\
\text { planning } \\
\text { instruction } \\
\text { suitable for } \\
\text { children }\end{array}$ \\
\hline \multirow{2}{*}{$\begin{array}{l}\text { Summer } \\
\text { experience, weeks } \\
2-8\end{array}$} & Monday & Tuesday & Wednesday & Thursday & Friday \\
\hline & $\begin{array}{l}\text { Write lesson } \\
\text { to address } \\
\text { children's } \\
\text { learning needs }\end{array}$ & $\begin{array}{c}\text { Practice } \\
\text { delivering lesson } \\
\text { and then use with } \\
\text { children }\end{array}$ & $\begin{array}{c}\text { View and } \\
\text { transcribe video } \\
\text { from Tuesday's } \\
\text { lesson }\end{array}$ & $\begin{array}{c}\text { Analyze } \\
\text { lesson transcripts } \\
\text { and begin } \\
\text { planning next } \\
\text { lesson }\end{array}$ & $\begin{array}{c}\text { Finish } \\
\text { leftover tasks } \\
\text { from the week }\end{array}$ \\
\hline \multirow{2}{*}{$\begin{array}{c}\text { Summer } \\
\text { experience, week } 9\end{array}$} & Monday & Tuesday & Wednesday & Thursday & Friday \\
\hline & $\begin{array}{c}\text { Reflect on } \\
\text { results of initial } \\
\text { interviews }\end{array}$ & $\begin{array}{c}\text { Prepare for } \\
\text { and conduct final } \\
\text { interviews with } \\
\text { children }\end{array}$ & $\begin{array}{c}\text { View and } \\
\text { transcribe final } \\
\text { interviews with } \\
\text { children }\end{array}$ & $\begin{array}{c}\text { Begin to } \\
\text { assemble poster } \\
\text { and abstract }\end{array}$ & $\begin{array}{c}\text { Begin to } \\
\text { assemble poster } \\
\text { and abstract }\end{array}$ \\
\hline \multirow{2}{*}{$\begin{array}{c}\text { Summer } \\
\text { experience, week } \\
10\end{array}$} & Monday & Tuesday & Wednesday & Thursday & Friday \\
\hline & $\begin{array}{l}\text { Assemble } \\
\text { poster and } \\
\text { abstract }\end{array}$ & $\begin{array}{c}\text { Assemble } \\
\text { poster and } \\
\text { abstract }\end{array}$ & $\begin{array}{c}\text { Assemble } \\
\text { poster and } \\
\text { abstract }\end{array}$ & $\begin{array}{c}\text { Finalize } \\
\text { poster and } \\
\text { abstract } \\
\end{array}$ & $\begin{array}{c}\text { Present } \\
\text { results to invited } \\
\text { faculty }\end{array}$ \\
\hline $\begin{array}{l}\text { Following fall } \\
\text { and spring } \\
\text { semesters }\end{array}$ & \multicolumn{5}{|c|}{ Undergraduates travel to disseminate results of research at undergraduate research conferences. } \\
\hline
\end{tabular}

Figure 2. Summary of the PATHWAYS journey

Professional identity formation is a dynamic process influenced by a variety of factors. Individual characteristics, prior experiences, and professional learning contexts all play roles in developing such an identity (Pillen, Beijaard, \& den Brok, 2013). Communities of practice in which individuals participate exert influence (Wenger, 1999). As individuals participate in such learning contexts, they reflect upon who they are and what they would like to become (Biejaard, Meijer, \& Verloop, 2004). The self-understandings they form in the process can be powerful, serving as self-fulfilling prophecies (Sfard \& Prusak, 2005). For a teacher, one's professional identity can influence the propensity to stay in teaching (Chong, Low, \& Goh, 2011), interactions with curriculum materials (Forbes \& Davis, 2008), professional decision-making (Beijaard, 1995), and, consequently, student achievement (Sammons et al., 2007).

Aspects of the PATHWAYS model resonate with themes in the literature about promoting individuals' identities as teachers and researchers. Ponte and Chapman (2008) observed that preservice teachers' identities can be fostered by encouraging self-reflection before, during, and after practice. Such reflection is valuable when it involves systemic investigation consisting of questioning practice, analyzing data, and reporting results. All of these activities are inherent to the PATHWAYS model. As preservice teachers engage in careful investigation of teaching practice, there is potential for the dichotomy between teaching and research to fade as the activities of reflection and inquiry become their primary concerns (Girod \& Pardales, 2001). Deep engagement with inquiry in an authentic context is also a factor that leads undergraduate researchers, across disciplines, to identify themselves more strongly as researchers and persevere toward graduate study (Hunter, Laursen, \& Seymour, 2006). Having a university faculty mentor also facilitates identity development as a researcher (Harrison, 2008). 


\section{Title of project}

\section{Introduction}

- Foreshadow the problem, using literature (e.g., research shows that students in the U.S. have trouble with topic X).

- Describe the purpose of the study (e.g., to explore students' thinking about topic $X$ and to intervene to help it develop)

- State the specific research questions for the study (e.g. How can students' mathematical proficiency be developed for topic $X$ ?)

Methodology - Participants and
procedure
- Grade level of students, \# of
students, student participation rate,
duration of instruction (seven 1-
hour sessions + interviews). Assign
pseudonyms to students.
Describe the goals of instruction in
terms of the CCSSM Content
Standards.
Describe overall PATHWAYS
instructional cycle integrating
teaching and research (see training
module completed in May) - a cycle
of continuous, iterative
improvement.

Methodology - Data gathering and analysis

- Describe the pre/post interview protocol and show 3-5 key sample items - select these on the basis of your research question.

- Describe procedures used to video record, transcribe code, and analyze the interviews, lessons, and student work samples.

\section{Empirical Teaching and Learning Trajectory:}

\begin{tabular}{|c|c|}
\hline $\begin{array}{l}\text { What were the most striking } \\
\text { observations about } \\
\text { students' mathematical } \\
\text { proficiency at this point? } \\
\text { Give examples of strengths } \\
\text { and weaknesses in } \\
\text { conceptual understanding, } \\
\text { procedural fluency, strategic } \\
\text { competence, adaptive } \\
\text { reasoning, and/or } \\
\text { productive disposition. Use } \\
\text { data to illustrate examples. }\end{array}$ & $\begin{array}{l}\text { Instructional cluster } 1 \\
\text { - Describe your main tasks } \\
\text { and/or activities for this } \\
\text { cluster of weeks and why } \\
\text { you selected those tasks } \\
\text { and activities (justify this } \\
\text { on the basis of literature } \\
\text { \& previously observed } \\
\text { student thinking). } \\
\text { - Present data on student } \\
\text { strengths and } \\
\text { weaknesses in terms of } \\
\text { the strands of } \\
\text { mathematical proficiency. }\end{array}$ \\
\hline
\end{tabular}

Instructional cluster 2
Describe your main tasks
and/or activities for this
cluster of weeks and why
you selected those tasks
and activities (justify this
on the basis of literature
\& previously observed
student thinking).
Present data on observed
student strengths and
weaknesses in terms of
the strands of
mathematical proficiency.

\begin{tabular}{|l|}
\hline Instructional cluster 3 \\
\hline Describe your main tasks \\
and/or activities for this \\
cluster of weeks and why \\
you selected those tasks \\
and activities (justify this \\
on the basis of literature \\
$\&$ previously observed \\
student thinking). \\
Present data on observed \\
student strengths and \\
weaknesses in terms of \\
the strands of \\
mathematical proficiency.
\end{tabular}

Post-Assessment Results
What were the most striking
observations about
students' mathematical
proficiency at this point?
Give examples of strengths
and weaknesses in
conceptual understanding,
procedural fluency, strategic
competence, adaptive
reasoning, and/or
productive disposition. Use
data to illustrate examples.

Reflection and discussion: Based on your observations about student learning, what are some of the most difficult CCSSM Standards to attain? What points in the learning progression are most difficult? In your experience, how might students be helped through difficult points in the learning progression? If you were to re-write the learning progression to make it more useful to teachers, which portions might you re-write (i.e., what should other teachers know before they attempt to teach this topic - what advice can you give that is not already in the learning progression?)

Figure 3. PATHWAYS poster template

Sfard and Prusak (2005) observed that definitions of "identity" have been elusive in research, and offered the following useful characterization:

In concert with the vision of identifying as a discursive activity, we suggest that identities may be defined as collections of stories about persons or, more specifically, as those narratives about individuals that are reifying, endorsable, and significant. The reifying quality comes with the use of verbs such as be, have, or can rather than $d o$, and with the adverbs always, never, usually, and so forth, that stress repetitiveness of actions. A story about a person counts as endorsable if the identitybuilder, when asked, would say that it faithfully reflects the state of affairs in the world. A narrative is regarded as significant if any change in it is likely to affect the storyteller's feelings about the identified person. The most significant stories are often those that imply one's memberships in, or exclusions from, various communities (pp. 16-17).

Sfard and Prusak added that identity narratives can consist of both actual and designated identities. Actual identities can be thought of as "consisting of stories about the actual state of affairs" (p. 18), and designated identities are those "consisting of narratives presenting a state of affairs which, for one reason or another, is expected to be the case, if not now then in the future" (p. 18). Ultimately, designated identities have the potential to become actual identities. A goal of undergraduate research, across disciplines, is to help undergraduates build 
designated identities as professionals and as researchers that subsequently become actual identities.

\section{INVESTIGATING PARTICIPANTS' EMERGING PROFESSIONAL IDENTITIES}

It is worth noting that Sfard and Prusak's (2005) characterization of identity is inclusive of stories told by a wide variety of individuals to a wide variety of audiences. We were most interested in a particular type of story: those that undergraduates would tell about themselves as teachers and researchers within the context of PATHWAYS and beyond. As Sfard and Prusak observed, "Being a part of our ongoing conversation with ourselves, the first-person self-told identities are likely to have the most immediate impact on our actions" (p. 17). To elicit firstperson, self-told identities, we designed an interview script (Appendix) with questions to prompt undergraduates to tell the stories of their participation in the project and future plans.

The eight undergraduates who participated in the first year of the PATHWAYS project were interviewed individually. The four advanced undergraduates are referred to with the pseudonyms Karen, Emily, Rachel, and Veronica. Their undergraduate research partners, respectively, are referred to with the pseudonyms Gabriela, Anna, Shantel, and Linda. Each undergraduate was interviewed by the second author of this manuscript. The first author was the PATHWAYS principal investigator and had worked extensively with each participant as part of the project. The second author had not previously met any of the participants. We believed the undergraduates would be more comfortable telling their stories to an individual not involved in the project, and that they would be more thorough in relating details to someone not yet familiar with their work. Interviews were conducted after each undergraduate had completed at least one PATHWAYS-related professional conference presentation. The interviewer asked all of the questions on the script but also introduced probing questions when an undergraduate's response needed further elaboration. Each interview was audio-recorded and transcribed.

The first author read each interview transcript and tagged identity-related excerpts. Of particular interest were those relating to perceived states of being or repetitive actions, which, in Sfard and Prusak's (2005) terms, are reifiable elements. Sfard and Prusak noted that reifiable elements are often indicated in narratives with verbs such as be and have and adverbs such as always, never, and usually. These verbs and adverbs were used as starting points in identifying reifiable elements in transcripts of participant narratives. As the transcripts were analyzed, additional words and phrases serving the function of indicating repetitive actions and states of being were identified. For example, one participant said that she was "in complete agreement" with inquiry-oriented instruction, and this was taken to indicate a state of being. Another participant spoke of the importance of constantly "pulling information" from students through questioning during lessons, and this was taken to indicate a repeated action she considered to be of importance when teaching. As such actions and states of being were indicated in each narrative, they were included among the reified elements identified by each participant.

Once identified, reified elements were given concise descriptions and then sorted into three professional identity categories: teacher, researcher, and teacher/researcher. Within each of these three categories, two additional subcategories were formed: one for utterances pertaining to actual identity and another for those about designated identity. The second author then reviewed the descriptors of reified elements and categorizations that had been formed. Based upon her interaction with the undergraduates and reading of the interview transcripts, she suggested modifications to descriptors and categorizations and also identified additional identity elements. Hence, the final identity element descriptors 
and categorizations reflected the combined judgment of an individual who had worked extensively with each undergraduate (the first author) and another just coming to know them (the second author). These descriptors and categorizations were then used to construct identity summary narratives for each participant, which are presented in the next section.

\section{ELEMENTS OF PATHWAYS PARTICIPANTS' PROFESSIONAL IDENTITIES}

This section consists of four sub-sections: one for each pair that worked together during the 10-week summer experience. For each pair, the advanced undergraduate's story is told first, and the beginning undergraduate's story is told second. This organizational scheme is meant to situate their individual stories within the context of their work with one another.

\section{Pair 1: Veronica and Linda}

During the summer, Veronica and Linda worked with a group of children finishing third grade. They studied the children's learning of fraction representation, equivalence, and comparison. After producing an abstract and poster about their project, they presented a poster together at the National Conference for Undergraduate Research (NCUR).

Veronica's story. Veronica identified as a future elementary school teacher who was already an advocate of problem-based learning before starting the program. When asked if PATHWAYS influenced her opinion of problem-based learning, she said,

I knew what I was going to get into; she [her methods instructor] trained us pretty well. But yeah I would say I grew with it. The program helped me grow that way, but changing the opinion? Not really changing it, but maybe growing it.

Veronica did, however, credit PATHWAYS with helping her become proficient at questioning students and providing them space to think. In discussing her work with the children, she stated,

I think at the beginning, I would be with them and be thinking, could I ask this? Should I ask this? And then at the end, it was like, I knew all the inquiry and open ended questions to ask them, um, without even hesitation, it was just natural... And I do see myself, you know I rarely ever, I try not to ever ask a yes or no question; I always try to just get them to think, or even if they're right or they're wrong, like you say, are you sure about that?

Veronica also spoke of becoming an advocate of collaborative teaching during PATHWAYS, valuing the ability to "bounce ideas" off one another during the summer, and believed that in the process she became a more proficient teacher of fractions.

Veronica identified herself as a proficient researcher in regard to gathering and organizing data. During the spring semester after PATHWAYS, she had to study the impact of her instruction on student learning as part of her student teaching internship. She stated,

I would say, really, I mean from PATHWAYS, and I just finished my student impact study for education, so from PATHWAYS and doing that, the student impact study was like a breeze. And, even completing the poster, and doing everything, was just like oh, I've done this...So it was, it just really prepared me, and honestly, now I'm really interested in research, and I never would've had that opportunity beforehand.

Veronica also expressed interest in ultimately publishing the findings of her research. Interestingly, however, she did not speak of research in the context of future plans for graduate school. She expressed the desire to ultimately become an 
administrator, a reading specialist, a school psychologist, or a university professor when asked about her graduate school plans, but did not speak of the opportunity to do research as part of the motivation for graduate study.

Linda's story. Like Veronica, Linda was working toward becoming an elementary school teacher. In re-telling her PATHWAYS experience, Linda described the development of her identity as a reflective teacher. This theme occurred in her observations about her teaching practices as well as in her observations of students' growth. She stated that her previous field experiences for education courses had been limited to classroom observations of other teachers. It was new for her to reflect on her own practice, using tools such as lesson video and student work samples. It was also new for her to reflect on student learning by analyzing classroom data, and she expressed the value she now placed on such reflection:

So we were able to take, not only what they were doing in the classroom, we were able to take their work samples and look at that and see how they were growing. But when we looked back, we can actually see their comprehension levels, as opposed to, you know, trying to focus on just four kids in one classroom. But you're able to individually go back with looking at the videos to see them, so that made it a little-you know, because sometimes, you think everyone gets it, but you look back and you see the eyes dart over to someone else's paper, and it's like mmm, I'm not really sure. So that was helpful.

Like her partner, Linda came to value collaboration with a peer as well as a faculty mentor, believing that she and Veronica "mixed well" and contributed equally to the work. She valued the opportunities they had to improve their questioning techniques and to motivate students.

The idea of integrating teaching and formal research was new to Linda. During her interview, she stated,

A lot of research I know you don't really have the opportunity to teach, I guess, um, so the way that this was centered around education, I liked that a lot. I've never done anything like it...I wish we could do it again...going, you know, across the country just to show people what we found, how things came out, it was amazing.

Although she identified herself as an enthusiastic teacher/researcher who enjoyed disseminating the results of her work, like Veronica, she did not associate graduate-level coursework with further pursuit of such endeavors. Linda spoke of having the goal of ultimately obtaining a doctoral degree - possibly in education, psychology, or sociology - but did not articulate a clear vision of the work she wished to do within those fields. She also did not appear to be concerned with defining such a vision, noting that she had changed her undergraduate major three times and simply enjoyed being a "lifelong learner" as a college student.

\section{Pair 2: Emily and Anna}

Emily and Anna worked with a group of children finishing third grade. Emily was working toward becoming an elementary school teacher, and Anna toward teaching secondary school mathematics. Their project involved researching and developing children's understanding of multiplication. They presented their work during a poster session at the National Association of Professional Development Schools (NAPDS) annual conference.

Emily's story. As she entered PATHWAYS, Emily wanted to specialize in mathematics as an elementary school teacher. She chose this designated identity because she believed it would make her more marketable. She also described herself as a "little kid person" and "not a reading person." Like Veronica, she identified with problem-based instruction to an extent upon entering the program because of her mathematics teaching methods course. Although this was part of her identity at the outset, Emily spoke of developing abilities to help realize her existing philosophy 
during PATHWAYS. In particular, she described her development as a skillful questioner who was able to capture student interest and explain things conceptually. Like Veronica, she spoke of the skills she developed carrying over into her student teaching internship:

I did my internship after this....and I taught math first in my internship, and that was much-it helped me a lot more, having done this, cause I'd teach them the math concept and then instead of just moving on when they had the correct answer, it would be like, well, why does that work? Or can you explain that more? Then my students got it more that they didn't just have to get the correct answer, they had to know why.

At several points in her interview, Emily described how much she enjoyed seeing the PATHWAYS children grow as she analyzed classroom data, further solidifying her commitment to problem-based teaching. She acknowledged her partner's role in the teaching and research process and saw collaboration as a valuable part of her future work, though she also felt that collaboration was sometimes difficult because her partner was a future secondary school teacher.

In speaking of her future plans, Emily clearly saw herself more as a teacher than as a researcher. She planned to complete a master's degree because graduate work would be required for teaching license renewal. Emily said that the PATHWAYS program had made her more comfortable in possibly pursuing a master's degree in mathematics education as opposed to just education. When asked if she planned to become a doctoral student in the future, she laughed and dismissed the idea. Despite her aversion to doctoral level study, Emily saw value in seeking out what others had written about effective teaching strategies as part of PATHWAYS and expressed a desire to become better at it. Her NAPDS conference presentation helped her begin to see herself as someone who would share her own teaching strategies with others. In discussing her presentation experience, Emily remarked, "I hadn't thought of ever doing that before the program (i.e., presenting teaching strategies)," and stated,

I think it gave me more confidence in explaining what we did, and how I would use that in my own classroom, cause they (i.e., conference attendees) would come up and ask you, how would you use this? And I would, 'Oh, well! This is how I would use it' (laughs).

So, although she did not identify herself as being engaged in formal creation of knowledge through research, Emily did identify with the role of sharing teaching strategies with others.

Anna's story. The idea of problem-based teaching was new to Anna as she entered PATHWAYS. When asked her opinion about it, she stated,

It was not necessarily something that I considered before, especially when it comes to full classroom. Maybe I have considered it as my own personal, um, pleasure, basically, to solve problems in that way. But I never, ever, ever considered that as being able to implement in the classroom. And after I experienced with it, I certainly would love to have the opportunity to do that in my own class.

Anna did, however, express some reservations about teaching in this manner in the future, stating, "I do have, um, second thoughts for that, but it's more of being unsure if it will work out, not, I don't have second thoughts whether I will try or not." She feared that high school students may not be open to new techniques. Nonetheless, she did identify herself as a careful analyst of students' thinking, speaking at length about her PATHWAYS students' thinking in terms of the five strands of mathematical proficiency, and saying she had to be careful "to not analyze too much" and to allow data to refute her initial thinking. Anna also felt that she became less "aggressive" by allowing space for students to think about problems rather than funneling them toward correct answers, and by being careful not to dominate the classroom when teaching collaboratively after viewing and transcribing the first teaching session. 
Anna had a clearly designated identity as a future mathematics education doctoral student. Her goal was to teach at the university level. When asked if she would be open to graduate study, she replied, "I am not open, I am doing it." She said that her goal of teaching at the university level was set before her participation in PATHWAYS. Participating in the project did, however, lead her to identify more strongly as a conductor and disseminator of research. In discussing her NAPDS poster presentation, she remarked,

To be able to share that with other professionals who are specifically interested in that topic, other third-grade teachers, or other just math professionals, I think it is important. I enjoy learning from others, so if I can help and share my experience with others, I think that is pretty important.

She also expressed a desire to publish her work, but at the same time expressed self-doubt about her ability to do so and a need for additional support.

\section{Pair 3: Karen and Gabriela}

Karen and Gabriela taught decimal representations and operations to a group of children finishing fourth grade. Karen's goal was to be an elementary school teacher, and Gabriela wanted to teach history at the high school level. They collaboratively presented their PATHWAYS summer work in a poster session at a Research Experiences for Undergraduates Symposium organized by the Council on Undergraduate Research.

Karen's story. Like Veronica and Emily, Karen was familiar with problem-based teaching as a result of her teaching methods course, and identified with it before the start of PATHWAYS. Karen spoke strongly about her reasoning for this position:

Problem-based learning is - I would tattoo it on my forehead - that's me... I see some of my peers that are 22 and are still looking for specific instructions rather than problem-solving on their own...Obviously it's our job to teach them decimals, teach them fractions... but it's also like teaching them how to be a human, you know? So if you can't problem solve, and you can't think critically and you're always looking for a specific, drawn-out instruction guide, then you're not going to be as successful.

Karen described how participation in PATHWAYS helped her realize the goal of problem-based teaching by developing her abilities to probe student thinking, carefully plan instruction, teach for depth of understanding, and collaborate with peers. When speaking of the most rewarding aspects of the PATHWAYS experience, she consistently put a premium on students' affective gains over cognitive gains. At one point, for example, when talking about how the children had progressed in participating in class sessions, she said, "they all were just so, their confidence, it was more important to me than their like, post-test, or whatever."

Although Karen clearly expressed her identity as an elementary school teacher, and was working as a math intervention instructor for grades 3,4 , and 5 at the time of the interview, her plans related to graduate study were less well-defined. She expressed the desire to be a school principal and also to be a university-level mathematics educator, like her PATHWAYS mentor, but did not explain how she might attain and reconcile both roles. She did, however, connect research to future graduate work when asked how PATHWAYS may have influenced her thinking about graduate school, stating, "I thought the research was cool, and then...at the end having to put everything together, and keeping all your evidence and your data together, and all that, I was like, oh, I could do that." Karen also felt that she developed her abilities to present to different audiences, having presented at a small concluding session on-campus during the summer and at an off-campus conference with researchers from diverse fields, and to locate literature on topics in mathematics education. 
Gabriela's story. Upon entering PATHWAYS, the idea of problem-based teaching was new to Gabriela. She initially identified with traditional teaching strategies. Gabriela summarized her transition to a different type of teaching by stating,

I kind of started off with an idea of teaching is, this is my knowledge, now you have to learn it, you know, and just kind of, like, absorb this! (laughs). You know, instead of really like exploring, and kind of playing with it, and just kind of, give me your idea on it, why do you understand it this way? And you know, kind of, I guess, letting them have their opinion instead of giving them mine.

Gabriela said that her change in teaching philosophy led her to be an advocate of the Common Core State Standards. She also identified herself as an advocate of collaborative teaching before starting PATHWAYS, and spoke of the program strengthening this position.

During the program, Gabriela's designated identity shifted away from secondary school teacher toward doctoral student in archaeology. After speaking with her mentor about graduate school opportunities, she became intrigued with archaeology programs at two specific graduate schools. Gabriela's decision to attend one of the two was consistent with her self-professed enthusiasm for research and perseverance in conducting it, which she felt she had already developed upon entering PATHWAYS. When speaking about the relationship between her future research and teaching at the university level, she said, "I would love to be able to do research in the summers, and kind of like do the field school, and then be able to bring that information back, and you know, teach it, and actually be first hand." Interestingly, the PATHWAYS model in which she had participated bore some resemblance to an archeology field school, with student researchers constructing disciplinary knowledge alongside faculty mentors.

\section{Pair 4: Rachel and Shantel}

Rachel and Shantel worked with a group of students finishing sixth grade. They helped children devise ways to describe centers of data sets. At the start of the program, both Rachel and Shantel identified as future secondary mathematics teachers. Rachel presented their work from the project in a poster session at NCUR, and Shantel presented it at an undergraduate poster session at an MAA sectional conference.

Rachel's story. Like many other participants, Rachel identified as an advocate of problem-based learning. When asked to evaluate problem-based learning, she said, "I think that although it's very challenging, if we can keep it engaging, I think that students benefit a lot more from it; from actually doing it and discovering it themselves than just listening to what they have to do." Rachel felt that her philosophy of teaching and learning made it difficult to collaborate with her partner, Shantel, whom she perceived as having a more traditional view. Nonetheless, Rachel spoke of the importance of collaboration with others when planning lessons. When asked what she learned about herself as a teacher, Rachel noted that she learned how patient she could be. She was also pleased with her ability to connect to students' interests, carefully assess students' progress, differentiate instruction, and use data to inform instructional decisions.

Before entering PATHWAYS, Rachel identified strongly as an undergraduate researcher, having done several independent projects with mathematics professors in the past. She had graduate school aspirations before starting the program. Rachel did, however, perceive her PATHWAYS experience to be different from the undergraduate mathematics research she had previously completed. She compared it to her previous experiences in the following manner:

I really liked what we were researching. I think it helps that we were researching students; I've actually done research in both the, just the math realm and the math 
education realm. And I tend to enjoy the math education realm because that's always changing, and I feel like each student's different. So I really like researching a certain group of students and then seeing, comparing it with another group to see the same, what's the same and what's different. So I really just liked researching how the students thought as opposed to, um, how something in mathematics works, because you can't really predict how they're going to think, um, without doing research.

In the interview, she repeatedly emphasized that she was interested in how students think about content, and not just about content alone. Rachel said that she valued the opportunities to inquire into students' thinking with probing questions and to observe their growth. In explaining how PATHWAYS influenced her goals for graduate school and research, Rachel stated,

I think all of my research combined made me think about what I wanted to do, because I had to do research in just a math field alone, it had me thinking do I want to still pursue the education side? Or do I go straight for math and just do research in math all the time, but PATHWAYS and my experiences in the high school and middle school have really helped me realize that I do want to do the education part, and I do love that so, and I think that PATHWAYS did enable me to see that I can do research in math and education, so I think it did help me realize what I wanted to do.

Given her experiences and interests, Rachel explained that she planned to pursue a doctoral degree in mathematics education after teaching secondary school mathematics.

Shantel's story. Shantel shared Rachel's perception that collaboration between the two of them was at times problematic and involved difficult compromises. Nonetheless, when asked how PATHWAYS influenced her views on collaborating with other educators, Shantel said,

It made me feel that you really do need teamwork, because you cannot just go into teaching alone, especially like your first year. I feel like if you have somebody that you can go back to, or have a mentor that's watching you, then you're going to be able to gain more perspective, and get into the feel of actually being there.

Shantel was less certain about the value of problem-based learning. When asked her position on problem based learning, she first paused, and then said, "It depends, because on problem-based learning, I feel like you should be able to know a lot of procedural to gain strength, but you also need to gain more conceptual understanding, and to be able to do a problem." Despite her uncertainty about the value of problem-based learning, Shantel identified as a reflective teacher and a proponent of the Common Core State Standards. Being a female teacher was another important part of her teaching identity. She said, "Women have their way of teaching, but I feel as if women, we feel like we just need to do everything in detail. Some men...they skip sections, thinking that it's easier for everybody to understand what they're thinking."

Shantel spoke of doing several collaborative undergraduate research projects in mathematics and computer science before and after PATHWAYS. She enjoyed disseminating research at conferences and in co-authored publications. These activities provided motivation for her to pursue a graduate degree. Shantel stated, "PATHWAYS actually made me think that I should go and just keep furthering it (i.e. her education) so that I can get more things published and be recognized for the different things that I do." Although PATHWAYS helped provide motivation in this manner, Shantel's designated identity was to be a mathematics doctoral student rather than one in mathematics education. When asked to explain this choice, she said,

I love math; math is everything. I feel like that's the only thing that I can just sit there and do it. Everybody always asks why do you want to do math? But I see myself as I can't do anything other, but math; I dream about math at night...wherever you go, you can't get away without doing math. 
When interviewed, she had narrowed her choices down to two particular doctoral programs in mathematics. Interestingly, she simultaneously retained her designated identity as a high school teacher, saying that she planned to pursue an alternative certification path for teaching high school after doing her doctoral degree in mathematics.

\section{DISCUSSION AND CONCLUSION}

Literature demonstrating the value of process-reflection models of teacher education is becoming increasingly prevalent (Ricks, 2011). Our findings about undergraduate identity development within the context of PATHWAYS add to this growing body of knowledge. The particular process reflection model used in PATHWAYS helped solidify advanced undergraduates' identities as proponents of problem-based teaching and introduced beginning undergraduates to the concept. It helped undergraduates, to varying degrees, see themselves as capable of implementing problem-based lessons. This is significant in light of widespread findings that undergraduates' initial experiences teaching children in conventional student teaching arrangements often diminish their commitment to reform-oriented ideas encountered in teaching methods classes (Clift \& Brady, 2005).

Given the results of the study, it is worth further exploring how PATHWAYS and similar models might mitigate the common erosion of undergraduates' identities as reform-oriented teachers during student teaching internships. Sfard and Prusak's (2005) identity framework could serve as a tool for such research endeavors. In particular, it would allow for the investigation of identity narratives from those who participate in a PATHWAYS-like model and then complete more conventional student teaching internships. Reified elements of PATHWAYS participants' narratives frequently related to their identities as inquiry-oriented instructors and teachers who continuously assess students' thinking. Many formed designated identities as future teachers who would continue along the same path. It would be of interest to see the extent to which these types of perceived states of being and repetitive actions persist in prospective teachers' identity narratives after a conventional student teaching internship. Going a step further, such post-internship narratives could be compared to the identity narratives of comparable groups who complete a conventional student teaching internship without the benefit of having participated in a PATHWAYS-like model first.

The phrase "PATHWAYS-like model" is, of course, somewhat imprecise, so it is worth considering what the essential elements of such a model might be. One way to do this is to compare it against similar projects and models. For example, some elements of Japanese Lesson Study (Stigler \& Hiebert, 1999) are clearly shared with the model. In particular, the PATHWAYS research and development cycle (Figure 1) involves continuous collaborative reflection on instruction that leads to iterative improvement of instructional approaches. This type of activity is also embedded in the "Iterative Model Project" (Weiland, Hudson, \& Amador, 2014). Like PATHWAYS, it draws students into a research and development cycle by having prospective teachers conduct clinical interviews with children. In both projects, prospective teachers use what they learn during clinical interviews to construct lessons that meet children's learning needs. Hence, the research and development cycles in Japanese Lesson Study, PATHWAYS, and the Iterative Model Building project all employ what Ricks (2011) called process reflection. Process reflection involves not merely reflecting on children's thinking and the instructional context in which it is developed, but also using those reflections as building blocks for future teaching plans.

The essential notion of process reflection is, then, perhaps the most generalizable and scalable element of the PATHWAYS model. Other elements, such as having a 
faculty member work with closely with two undergraduates for an extended period of time, may be more difficult to implement on a large scale because of limited resources. The process reflection element of PATHWAYS can be employed even in models that do not follow the PATHWAYS model precisely. For example, conventional student teaching internship models could be modified to incorporate process reflection. This might be accomplished through groups of student teaching interns engaging with their colleagues through Japanese Lesson Study or similar arrangements. There is a danger, however, that such activity may be perceived as an "add-on" to the conventional model and become a peripheral rather than central part of it. A serious commitment to such a model would entail making process reflection the driving engine of daily activity rather than an extra task for prospective teachers to do. Only when process reflection assumes a central role of this nature could its impact on prospective teachers' development in comparison to more conventional arrangements be accurately assessed.

As an undergraduate research model, PATHWAYS was also designed to encourage participants to pursue graduate study, or, in other words, to encourage the formation of designated identities as future mathematics education researchers. The extent to which it did so varied. For example, Rachel spoke of her experience as clarifying her designated identity as a mathematics education doctoral student rather than a doctoral student in mathematics; her partner, Shantel, had her resolve strengthened to pursue mathematics rather than mathematics education. This sort of clarification of goals for graduate study is a fairly common phenomenon during undergraduate research experiences (Russell, Hancock, \& McCullough, 2007). Anna developed skills in disseminating research that she believed would serve her in her future doctoral study in mathematics education. The others had less clearly defined designated identities as graduate students or were set on pursuing graduate study in another field. One area for improvement of the model would be to develop strategies to help those with less clearly defined designated identities for graduate study consider mathematics education doctoral study more seriously, given the shortages in the field (Reys et al., 2013). Such strategies might include more explicit attention to having faculty mentors relate the stories of their own identity development as mathematics education doctoral students, given the influence that the mentor relationship can have on personal identity development (Harrison, 2008). Undoubtedly, mentoring is a resource-intensive process, so it is a fairly difficult element of the PATHWAYS model to implement on a large scale. Nonetheless, given previous literature and the experiences described in this report, it appears to be an indispensable aspect of programs that seek to help undergraduates develop designated identities as formal mathematics education researchers.

For the field of mathematics education to continue to grow and mature, we need aspiring teachers who can help students develop mathematical knowledge and can also create knowledge in the field of mathematics education to disseminate to other professionals. The PATHWAYS model has shown some potential to help undergraduates develop actual and designated identities relevant to supporting these dual roles. As is true of any model, it can benefit from further research, development, and discussion among the professional community. We hope that our description of the model and accounts of PATHWAYS undergraduates' emerging identities will stimulate further conversations about leveraging undergraduate research to develop effective mathematics teachers and encourage graduate study in mathematics education. 


\section{ACKNOWLEDGEMENT}

This research was supported by the National Science Foundation (NSF) under award DRL-1356001. The views expressed herein are those of the authors and do not necessarily reflect those of the NSF.

\section{REFERENCES}

American Association of Colleges for Teacher Education \& Stanford Center for Assessment, Learning, and Equity. (2015). edTPA. Retrieved from http://edtpa.aacte.org/

Ball, D. L. (2003). Mathematical proficiency for all students: Toward a strategic research and development program in mathematics education. Santa Monica, CA: RAND.

Beijaard, D. (1995). Teachers' prior experiences and actual perceptions of professional identity. Teachers and Teaching: Theory and Practice, 1(2), 281-294. doi: 10.1080/1354060950010209

Beijaard, D., Meijer, P. C., \& Verloop, N. (2004). Reconsidering research on teachers' professional identity. Teaching and Teacher Education, 20, 107-128. doi:10.1016/j.tate.2003.07.001

Chong, S., Low, E. L., \& Goh, K. C. (2011). Emerging professional identity of pre-service teachers. Australian Journal of Teacher Education, 36(8), 50-64.

Clift, R. T., \& Brady, P. (2005). Research on methods courses and field experiences. In M. Cochran-Smith \& K.M. Zeichner (Eds.), Studying teacher education: The report of the AERA Panel on Research and Teacher Education (pp. 309-424). Mahwah, NJ: Erlbaum.

Common Core State Standards Writing Team. (2011). Progression for the Common Core State Standards for Mathematics (Draft), K-5, Measurement and data. Retrieved from http://commoncoretools.files.wordpress.com/2011/06/ccss_progression_md_k5_2011 _06_20.pdf

Confrey, J., Maloney, A. P., Nguyen, K. H., Mojica, G., \& Myers, M. (2012). TurnOnCCMath.net: Learning trajectories for the K-8 Common Core math standards. Retrieved from https://www.turnonccmath.net

Council on Undergraduate Research. (2015). Student events. Retrieved from http://www.cur.org/conferences_and_events/student_events/

Dewey, J. (1933). How we think: A restatement of the relation of reflective thinking to the educative process. Boston: Heath.

Educational Testing Service. (2015). The Praxis performance assessment for teachers. Retrieved from http://www.ets.org/ppa/

Ellemor-Collins, D. L., \& Wright, R. J. (2008). Student thinking about arithmetic: Videotaped interviews. Teaching Children Mathematics, 15, 106-111.

Ferrini-Mundy, J. (2011). Dear colleague letter: Opportunity for Research Experiences for Undergraduates (REU) sites focusing on STEM education research. Arlington, VA: National Science $\quad$ Foundation. Retrieved from http://www.nsf.gov/pubs/2011/nsf11076/nsf11076.jsp

Forbes, C. T., \& Davis, E. A. (2008). The development of pre-service elementary teachers' curricular role identity for science teaching. Science Education, 92, 909-940. doi: 10.1002/sce.20265

Girod, M., \& Pardales, M. (2001, April). “Who am I becoming?" Identity development in becoming a teacher-researcher. Paper presented at the Annual Meeting of the American Educational Research Association, Seattle, WA.

Harrison, R. L. (2008). Scaling the ivory tower: Engaging emergent identity as a researcher. Canadian Journal of Counselling, 42(4), 237-248.

Hu, S., Scheuch, K., Schwartz, R., Gaston-Gayles, J., \& Li, S. (2008). Reinventing undergraduate education: Engaging college students in research and creative activities. ASHE Higher Education Report, 33(4), 1-103.

Hunter, A. -B., Laursen, S. L., \& Seymour, E. (2006). Becoming a scientist: The role of undergraduate research in students' cognitive, personal, and professional development. Science Education, 91(1), 36-74. doi: 10.1002/sce.20173 
Ingersoll, R. M., \& Perda, D. (2010). Is the supply of mathematics and science teachers sufficient? American Educational Research Journal, 47, 563-594. doi: $10.3102 / 0002831210370711$

Jenkins, O. F. (2010). Developing teachers' knowledge of students as learners of mathematics through structured interviews. Journal of Mathematics Teacher Education, 13, 141-154. doi: $10.1007 / \mathrm{s} 10857-009-9129-9$

Kilpatrick, J., Swafford, J. and Findell, B. (Eds.). (2001). Adding it up: Helping children learn mathematics. Washington, DC: National Academy Press.

McDonough, A., Clarke, B., \& Clarke, D. M. (2002). Understanding, assessing and developing children's mathematical thinking: The power of a one-to-one interview for preservice teachers in providing insights into appropriate pedagogical practices. International Journal of Educational Research, 37, 211-226. doi:10.1016/S0883-0355(02)00061-7

Lappan, G., Fey, J. T., Fitzgerald, W. M., Friel, S. N., Phillips, E. D. (2009). Connected mathematics project 2. Boston: Pearson.

Learn NC \& Wheatley, G. (2001). Problem centered math. Retrieved from http://www.learnnc.org/lp/editions/pcmath/cover

National Governors Association for Best Practices \& Council of Chief State School Officers. (2010). Common core state standards for mathematics. Retrieved from http://www.corestandards.org/

Pillen, M., Beijaard, D., \& den Brok, P. (2013). Tensions in beginning teachers' professional identity development, accompanying feelings and coping strategies. European Journal of Education, 36(3), 240-260. doi: 10.1080/02619768.2012.696192

Ponte, J. P., \& Chapman, O. (2008). Preservice mathematics teachers' knowledge and development. In L.D. English \& D. Kirshner (Eds.), Handbook of international research in mathematics education (2nd ed., pp. 223-261). New York: Routledge.

Reys, B. J., \& Reys, R. E. (2004). Recruiting mathematics teachers: Strategies to consider. Mathematics Teacher, 97, 92-95.

Reys, R. E., Reys, B., \& Estapa, A. (2013). An update on jobs for doctorates in mathematics education at institutions of higher education in the United States. Notices of the AMS, 60, 470-473.

Ricks, T. E. (2011). Process reflection during Japanese Lesson Study experiences by prospective secondary mathematics teachers. Journal of Mathematics Teacher Education, 14, 251-267. doi: 10.1007/s10857-010-9155-7

Russell, S. H., Hancock, M. P., \& McCullough, J. (2007). Benefits of undergraduate research experiences. Science, 316, 548-549. doi: 10.1126/science.1140384

Sammons, P., Day, C., Kington, A., Gu, Q., Stobart, G., \& Smees, R. (2007). Exploring variations in teachers' work, lives and their effects on pupils: Key findings and implications from a longitudinal mixed-methods study. British Educational Research Journal, 33, 681-701. doi: 10.1080/01411920701582264

Schön, D. A. (1983). The reflective practitioner: How professionals think in action. New York: Basic Books.

Sfard, A., \& Prusak, A. (2005). Telling identities: In search of an analytic tool for investigating learning as a culturally shaped activity. Educational Researcher, 34(4), 14-22. doi: 10.3102/0013189X034004014

Stigler, J. W., \& Hiebert, J. (1999). The teaching gap. New York, NY: Free Press.

Weiland, I. S., Hudson, R. A., \& Amador, J. M. (2014). Preservice formative assessment interviews: The development of competent questioning. International Journal of Science and Mathematics Education, 12, 329-352.

Wenger, E. (1999). Communities of practice: Learning meaning and identity. Cambridge: Cambridge University Press.

\section{APPENDIX}

Script for interviewing PATHWAYS undergraduates

1. Describe your experience with the online modules.

- What activities and readings were most helpful?

- Which activities and readings did you feel could be improved? 
2. Describe your experience with the video-based clinical interviews you conducted.

- Did you notice any changes in your questioning techniques between your pre-assessment and post-assessment interview?

- Do you think the questioning techniques you used in clinical interviewing will influence your teaching; why or why not?

3. Describe what you learned about gathering and analyzing data throughout the PATHWAYS project. Which aspects of data gathering and analysis did you enjoy? Which did you not enjoy? Please explain.

4. Describe your students' progress throughout the program in terms of the Five Strands of Mathematical Proficiency.

- What were some successes you experienced with your students throughout the program?

- What were some challenges you experienced with your students throughout the program?

5. Discuss your mentor's role in assisting you with the research process and helping you design instruction.

6. What was your experience like with your peer teaching partner?

7. What was the most memorable or rewarding experience you gained from your participation in the PATHWAYS program?

8. Do you have any suggestions for improving the PATHWAYS program moving forward?

Questions Related to Participants' Teaching Philosophies

9. What is your opinion on problem-based learning as opposed to conventional teaching strategies in mathematics?

- Did participation in the PATHWAYS program alter this opinion?

- If so, how and why? If not, why not?

10. Did participation in the PATHWAYS program contribute to a deeper understanding of the Common Core Standards?

- If so, in what ways?

- If not, discuss why, and what could be done differently to assist with this?

Questions Related to Participants' Feelings about Research and Future Plans

11. What aspects did you most enjoy about the research you conducted for this program?

12. What parts of the research process did you find most challenging?

13. What did you learn about yourself as a researcher?

14. What did you learn about yourself as a teacher?

15. What research presentations and publications have you done as a result of PATHWAYS?

- What did you learn from doing these presentations/publications that you would not have learned otherwise?

- Do you think you would like to do more presentations/publications as part of your professional work in the future? Why or why not?

16. How did this project contribute to the way you feel about collaborating with other educators?

17. How will this project impact what you do in your own classroom?

18. When do you plan to graduate?

19. What degree will you obtain?

20. Describe your plans for graduate school.

a. Do you plan to pursue a master's degree in education or mathematics education? Why or why not?

b. Do you plan to pursue a doctoral degree in education or mathematics education? Why or why not? 
c. Do you plan to pursue a master's or doctoral degree in any other field? Why or why not?

d. Did your PATHWAYS experience in any way impact your thinking about pursuing a graduate degree? Why or why not?

21. Is there anything else you would like to share about your PATHWAYS experience?

\section{$\diamond \diamond \diamond$}

